\title{
Translation, Cultural Adaptation and Validation of the Current Opioid Misuse Measure for European Portuguese
}

\author{
Tradução, Adaptação Cultural e Validação da Escala de \\ Uso Indevido de Opióides para Português de Portugal
}

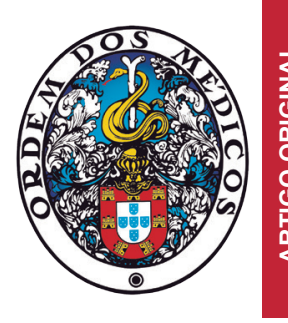

\author{
Diogo MENDES-MORAIS $\square^{1}$, Cláudia JANTARADA², Luís GUIMARÃES-PEREIRA ${ }^{1,2}$ \\ Acta Med Port 2020 Apr;33(4):261-268 - https://doi.org/10.20344/amp.12015
}

\begin{abstract}
Introduction: Current practice guidelines recommend using Current Opioid Misuse Measure to screen aberrant opioid-related behaviors in chronic pain patients. Our aims were to translate, adapt and validate it to be used in Portuguese chronic pain patients.

Material and Methods: Translation and cultural adaptation process followed guidelines and a model of principles for good practice. Adult chronic pain patients on opioid therapy, from one major hospital in Portugal, were invited to complete the translated version. Descriptive statistics, Cronbach's alpha, inter-item, item-total and intra-class correlation coefficients and principal components analysis were applied.

Results: Translation process was performed as planned and the validation sample was composed by 98 patients (median age $=62.5$ years). Regarding internal consistency, a global Cronbach's alpha of 0.778 was obtained and item-total correlations of all items were above 0.20 with four exceptions. An intra-class correlation coefficient of 0.90 was found between test and retest. Regarding validity, all 17 items presented a content validity index above 0.80 . Six principal components were extracted and explained $66.3 \%$ of the variance. Discussion: The Portuguese version of Current Opioid Misuse Measure was properly translated, adapted and validated; showing good quality in terms of reliability and validity. This is the first instrument to screen aberrant opioid-related behaviors in Portuguese chronic pain patients. Consequently, it will aid and promote the identification of opioid misuse in these patients.

Conclusion: The implementation of this questionnaire may reduce the incidence and morbimortality of opioid misuse among chronic pain patients and should improve chronic pain treatment in Portugal.

Keywords: Analgesics, Opioid/adverse effects; Opioid-Related Disorders; Portugal; Reproducibility of Results; Surveys and Questionnaires; Translating
\end{abstract}

\section{RESUMO}

Introdução: Orientações atuais recomendam a utilização da Escala de Uso Indevido de Opióides para rastrear comportamentos aberrantes, relativos ao uso de opióides em dor crónica. Os objetivos foram a sua tradução, adaptação cultural e validação para a população portuguesa com dor crónica.

Material e Métodos: O processo de tradução e adaptação cultural seguiu as recomendações. Adultos com dor crónica medicados com opióides, seguidos num hospital português de grande dimensão, foram convidados a completar a versão traduzida. Recurso a estatística descritiva, alfa de Cronbach, correlações inter-item, item-total, intra-classe, e análise de componentes principais.

Resultados: A tradução decorreu conforme planeado e a amostra de validação foi de 98 doentes (mediana de idades $=62,5$ anos). Relativamente à consistência interna, alfa Cronbach global $=0,778$, correlações item-total dos itens $>0,20$ (quatro exceções), e coeficiente de correlação intra-classe $=0,90$ (entre teste e reteste). Relativamente à validade, os 17 itens apresentaram um índice de validade de conteúdo > 0,80. Extraíram-se seis componentes principais, que explicaram $66,3 \%$ da variância.

Discussão: A versão portuguesa da Escala de Uso Indevido de Opióides foi adequadamente traduzida, adaptada e validada; demonstrando boa qualidade relativamente à confiabilidade e validade. Este é o primeiro instrumento para rastrear comportamentos aberrantes, relativos ao uso de opióides em portugueses com dor crónica. Consequentemente, ajudará e promoverá a identificação do uso indevido de opióides nestes doentes.

Conclusão: A implementação deste questionário poderá reduzir a incidência e morbimortalidade do uso indevido de opióides em doentes com dor crónica, e deverá melhorar o tratamento da dor crónica em Portugal.

Palavras-chave: Analgésicos Opióides/efeitos adversos; Inquéritos e Questionários; Perturbações Relacionadas ao Uso de Opióides; Portugal; Reprodutibilidade dos Testes; Tradução

\section{INTRODUCTION}

Chronic pain is recognized as a great public health problem with both physical, psychological and social impact. ${ }^{1}$ Recent population-based surveys in various countries have consistently estimated that $25 \%-35 \%$ of adults report chronic pain. ${ }^{2-6}$ Regarding Portugal, its prevalence was estimated to be $36.7 \%{ }^{7}$ Despite multiple pain management guidelines, there is still a reluctance to apply evidencebased and validated strategies in pain management. ${ }^{8} \mathrm{~A}$ major element contributing to this unacceptable situation is the

pervasive negative bias that exists regarding opioid use. ${ }^{8}$

Opioid analgesics are therapeutic options for those experiencing both cancer-related or noncancer-related chronic pain. ${ }^{9}$ There are enormous variations in opioid use across the globe, and even within regions, similar variations are observed. ${ }^{8}$ In Portugal, the prevalence of its use by patients with chronic pain is estimated to be $4.37 \% .{ }^{10}$ Opioids should only be introduced when strictly necessary and with due regard to an ongoing risk benefit analysis. ${ }^{8}$ They should be

\footnotetext{
1. Faculty of Medicine. University of Porto. Porto. Portugal.

2. Department of Anesthesiology. Centro Hospitalar São João. Porto. Portugal.

$\triangle$ Autor correspondente: Diogo Mendes Morais. mimed1303907@med.up.pt

Recebido: 13 de março de 2019 - Aceite: 27 de setembro de 2019 | Copyright @ Ordem dos Médicos 2020
} 
used as part of a multifaceted strategy that includes all necessary adjuvant analgesics, non-drug interventions, psychological support and rehabilitation. ${ }^{8}$ Opioid use in chronic pain treatment is complex, as patients may derive both benefit and harm. Common side effects of opioid administration include sedation, dizziness, nausea, vomiting, constipation, physical dependence, tolerance, and respiratory depression. ${ }^{11}$ With all opioids, respiratory depression and death are the most feared complications. ${ }^{11}$

Physical dependence and addiction are clinical concerns that may prevent proper prescribing and in turn inadequate pain management. ${ }^{11}$ Although long-term opioid therapy can be an effective chronic pain management treatment, a recent meta-analysis identifies rates of misuse between $21 \%$ and $29 \%$ of patients with chronic pain in opioid treatment. ${ }^{12}$ Identification of individuals currently misusing opioids is important given the substantial recent increases in prescription rates and consequent increases in morbidity and mortality. ${ }^{12}$ Activity limitations in daily life, co-morbidities, such as depression and anxiety, and lack of social relationships can contribute to misuse of opioid therapy. ${ }^{9}$ Clinical guidelines emphasize the need for regular assessment and management of risk associated with misuse as an integral part of safe opioid prescribing practices. ${ }^{13}$ Strategies such as pill counts, urine toxicology screening, and prescription drug monitoring programs may provide potentially useful information about risk. However, each of these strategies has important limitations. ${ }^{14}$ Self-report instruments may be one viable strategy for capturing aberrant opioid-related behaviors. ${ }^{14}$ Aberrant opioid-related behaviors are a wide range of behaviors that fall outside those expected in opioid treatment. ${ }^{15}$ They range from borrowing or stealing opioid medication from others, to patient-initiated dose escalation or concurrent use of an illicit substance. ${ }^{16}$

Current practice guidelines recommend using the Current Opioid Misuse Measure (COMM) to assess patients who are prescribed opioid therapy. ${ }^{13}$ The COMM, developed by Butler et al, ${ }^{17}$ is a validated self-reported instrument to screen aberrant opioid-related behaviors in chronic pain patients. This instrument has been translated to other languages, ${ }^{18}$ but so far there is no Portuguese version.

The aims of this study were to translate, adapt and validate the COMM to be used in chronic pain patients in Portuguese population.

\section{MATERIAL AND METHODS}

\section{The instrument}

The COMM questionnaire consists of a 17-item instrument that uses a 5-point Likert scale, ranging from 0 (never) to 5 (very often). A total score of 9 or higher is considered positive, meaning that a patient could be misusing their medication.

\section{Translation and cultural adaptation procedures}

In order to develop a valid Portuguese version of COMM, the study followed guidelines and a model of principles for good practice in the translation and cultural adaptation process. ${ }^{19}$

The translation process is described as follows: preparation, forward translation, reconciliation, back translation, back translation review and harmonization, cognitive debriefing, review of cognitive debriefing results and finalization and proofreading.

- Preparation: A preliminary permission to translate and validate the questionnaire was obtained from its original authors. They were also invited to be involved in the translation process in order to clarify concepts behind the 17 questions.

- Forward translation: The questionnaire, as well as an explanation of the basic concepts of the instrument, was given to two English interpreters who were Portuguese native speakers in order to obtain two independent translations of COMM.

- Reconciliation: A third element analyzed both documents. The differences were amended, and a single questionnaire was obtained.

- Back translation, back translation review and harmonization: A copy of the Portuguese version of the COMM was given to an English schoolteacher, with no prior knowledge of the original content, in order to avoid any influence on the translation of the words and a back-translation of the questionnaire was obtained. Comparison of the back-translated version with the original English language instrument was made and possible discrepancies were documented and analyzed. Approval of the back-translated version was obtained from the original questionnaire authors.

- Cognitive debriefing: A pretest of an intermediate Portuguese version, in a pilot group of individuals with chronic pain on opioid therapy, was made in order to assess comprehensibility. In this process, subjects made comments on the meaning, interpretation and any potential ambiguity for each item.

- Review of cognitive debriefing results and finalization: Comments were reviewed, and discrepancies were amended. The findings of the pretest were incorporated to improve the performance of the translation. The authors of the original scale were informed.

- Proofreading: The final version of the questionnaire was proofread to check for minor errors missed during the translation process.

\section{Patients, settings and data collection}

The study was approved by the Ethics Committee of the Centro Hospitalar Universitário de São João (CHUSJ) - CES 283-18.

Eligible patients who visited the Chronic Pain Unit of CHUSJ between October 2018 and January 2019 were invited to complete the Portuguese version of COMM. All patients included in the study participated voluntarily, were informed about its aims, its anonymity and confidentiality, and signed an informed consent before questionnaire 
completion. The questionnaire was completed in a quiet and private room.

Eligible patients were identified by checking the electronic medical records. Inclusion criteria: to be 18 or older, to have chronic pain and to be currently on opioid therapy for at least one month. Patients who were unable to give informed consent, who could not read and with whom communication was impaired were excluded.

Several characteristics of the patients were collected: age, gender, marital status, education level, occupation, smoking habits, alcohol consumption (a drink was defined as a $100 \mathrm{~mL}$ glass of table wine or a $330 \mathrm{~mL}$ can of beer), pain classification according to the International Classification of Diseases $11^{\text {th }}$ Revision (ICD-11), opioid medication and duration of opioid treatment.

\section{Application}

After the translation process, the final version of the Portuguese version of COMM was applied in a convenience sequential sample in order to evaluate its internal consistency and validity. There are no absolute rules for the sample size needed to validate a questionnaire and we followed the guidelines of a respondent-to-item ratio of $5: 1 .^{20}$ Thus, as this scale contains 17 items, the sample should include 85 subjects $(5 \times 17)$. To account for $15 \%$ of withdrawals, the sample size was increased to 100 subjects.

A month later, a retest, using a randomized sample, was done via telephone in order to evaluate test-retest reliability. Similarly, there are no absolute rules on the number of patients participating in the test-retest phase. After reviewing the literature on validation studies of pain questionnaires, ${ }^{18,21,22}$ usually the test-retest phase is applied to 5 to $20 \%$ of the total subjects. Therefore, we decided to apply it to $17 \%$ of them.

Additionally, a panel of experts in chronic pain were invited to evaluate the content equivalence of the COMM using content validity index (CVI), which consists in a 4-point rating scale $(1=$ not relevant; 2 = somewhat relevant; $3=$ quite relevant; 4 = highly relevant). The CVI is the percentage of agreement of all items rated by the experts as either three or four, and an CVI of 0.8 or greater is generally considered to be an indicator of good content validity. ${ }^{23}$

\section{Statistical methods}

Statistical analyses were performed with Statistical Package for The Social Sciences (SPSS) ${ }^{\circledR}$ version 25.0. Descriptive statistics of patient characteristics and clinical variables were expressed as frequencies with percentages (\%), median with interquartile range or mean with standard deviation (SD) when appropriate. Statistical significance was set at $p<0.05$.

In order to access the internal consistency of the questionnaire, Cronbach's alpha coefficients, inter-item correlation matrix analysis (using Spearman coefficient) and corrected item-total correlations were used. A Cronbach's alpha between 0.70 and 0.95 and item-total correlation of $>$ 0.20 were defined to be acceptable. ${ }^{24-26}$
Test-retest reliability was evaluated by calculating intraclass correlation coefficients (ICC) with 95\% Confidence Intervals $(95 \% \mathrm{CI})$. An ICC higher than 0.80 was considered acceptable. ${ }^{27}$

Construct validity for the COMM was evaluated by principal components analysis with Oblimin rotation. We conducted the Kaiser-Meyer-Olkin (KMO) measure and Bartlett's test to determine if there was a statistically significant correlation among items. ${ }^{28}$ Regarding factor loadings, a value of 0.40 or greater for the factor loadings was considered acceptable. $^{29}$

\section{RESULTS}

\section{Translation and cultural adaptation procedures}

The several steps of the translation process were performed as planned. Regarding, cognitive debriefing, eight subjects were recruited in the pilot trial, and the goal was to find language discrepancies and suit the questionnaire to Portuguese patients. Question number 10 ("Nos últimos 30 dias, com que frequência esteve preocupado com o modo como está a controlar a sua medicação?") was contested by a large number of patients and a reformulation was made. We add specific negative feelings in order to ensure

Table 1 - Socio-demographic characteristics of our group of patients $(\mathrm{n}=98)$

\begin{tabular}{lc}
\hline Age, Median $\left(\mathbf{P}_{25}-\mathbf{P}_{75}\right)$ & $62.5(55.0-73.0)$ \\
Education level in years, Median $\left(\mathbf{P}_{25}-\mathbf{P}_{75}\right)$ & $4.0(4.0-9.0)$ \\
Gender, $\mathbf{n}(\%)$ & \\
Male & $38(38.8)$ \\
Female & $60(61.2)$
\end{tabular}

Marital Status, $\mathbf{n}(\%)$

Single

Married

$69(70.4)$

Divorced

Widowed

Smoking habits, $\mathbf{n}(\%)$

None

1 - 10 cigarettes

11 - 20 cigarettes

Alcohol, n (\%)

Never

0 - 2 drinks per week

3 - 5 drinks per week

$>5$ drinks per week

Occupation, $\mathbf{n}(\%)$

Full time worker

$14(14.3)$

Partial time worker

Unemployed

$11(11.2)$

Domestic

Retired

$57(58.2)$

Unable to work

$12(12.2)$

SD : standard deviation; $P_{25}$ : percentile $25 ; P_{75}$ : percentile 75 
distinctness: "por exemplo, sentimentos de angústia, ansiedade, medo e/ou raiva".

The final version of COMM for European Portuguese is presented in the supplementary material (Appendix 1 (see Appendix 1: https://www.actamedicaportuguesa.com/revista/index.php/amp/article/view/13435/Appendix_01.pdf).

\section{Socio-demographic and descriptive characteristics}

The planed sample was composed of 100 patients. Two of them were excluded due to improper filling of questionnaire, resulting in a total sample of 98 patients. Socio-demographic characteristics are shown in Table 1. The median age was 62.5 (55.0 - 73.0), each patient had a median of $4(4.0-9.0)$ years of education and most of them were females $(61.2 \%)$. The patients were mostly retired $(58.2 \%)$, married $(70.4 \%)$, non-smokers $(87.8 \%)$ and denied alcohol consumption (68.4\%).

Table 2 displays opioid therapy and pain classification presented by patients, according to the ICD-11. Each patient was, on average, using an opioid for $29.9 \pm 32.3$ months and the most common were tapentadol (27.6\%), tramadol $(26.5 \%)$, fentanyl $(13.3 \%)$ and buprenorphine

Table 2 - Opioid medication, months of treatment and chronic pain classification of our group of patients $(n=98)$

\begin{tabular}{lc}
\hline Months of opioid treatment, mean (SD) & $29.9(32.3)$ \\
Opioid Medication, $\mathbf{n}(\%)$ & \\
Buprenorphine & $10(10.2)$ \\
Buprenorphine and Morphine & $1(1.0)$ \\
Buprenorphine and Tramadol & $3(3.0)$ \\
Fentanyl & $13(13.3)$ \\
Fentanyl and Buprenorphine & $1(1.0)$ \\
Fentanyl and Tramadol & $2(2.0)$ \\
Hydromorphone & $5(5.1)$ \\
Hydromorphone and Tramadol & $1(1.0)$ \\
Morphine & $3(3.1)$ \\
Morphine and Fentanyl & $2(2.0)$ \\
Oxycodone & $2(2.0)$ \\
Tapentadol & $27(27.6)$ \\
Tapentadol and Fentanyl & $1(1.0)$ \\
Tapentadol and Tramadol & $1(1.0)$ \\
Tramadol & $26(26.5)$ \\
Chronic pain classification (according ICD-11) & \\
Cancer related pain & $7(7.1)$ \\
Central neuropathic pain & $2(2.0)$ \\
Peripheral neuropathic pain & $10(10.2)$ \\
Postsurgical or post traumatic pain & $14(14.3)$ \\
Primary headache or orofacial pain & $1(1.0)$ \\
\hline Primary musculoskeletal pain & $3(3.1)$ \\
Secondary musculoskeletal pain & $41(41.8)$ \\
Sidespread pain & $8(8.2)$ \\
Pandard deviation & $12.2)$ \\
\hline
\end{tabular}

$(10.2 \%)$. It is relevant to note that a wide variety of opioids was being used in our sample. Besides that, a considerable number of patients were on monotherapy using strong opioids. Chronic musculoskeletal pain was the most frequent pain classification ( $50 \%$ of patients).

The final version of COMM for European Portuguese and its summary measures for each item are presented in Table 3. The highest average score was $1.84 \pm 1.47$ on the first question followed by $10^{\text {th }}(1.17 \pm 1.40), 11^{\text {th }}(1.15$ $\pm 1.43), 13^{\text {th }}(1.09 \pm 1.19)$ and $6^{\text {th }}(1.05 \pm 1.10)$. Questions 9 and 15 had very low average scores (0.02 and 0.01 , respectively).

\section{Internal consistency}

A global Cronbach's alpha of 0.778 was found.

Table 4 and Table 5 show the Inter-item correlation matrix, Item-total correlations and Cronbach's Alpha if item deleted. Some items showed weak or even negative inter-item correlations, suggesting that the questionnaire is a multidimensional tool. Item-total correlations of all items were above 0.20 with four exceptions: question $9,12,15$ and 17 had low item-total correlations. Finally, deletion of items 12 and 17 would result in the highest increase in Cronbach's alpha.

\section{Test retest reliability}

A retest with 17 randomly selected patients was performed one month later ( $17 \%$ of 98 patients). The mean score of the first application of COMM was $13.9 \pm 9.3$ and the retest $18.0 \pm 11.5$. An ICC of $0.90(95 \% \mathrm{Cl}: 0.76-0.96)$ was found between test and retest.

\section{Validity}

All the 17 items showed a CVI above 0.8, which indicates that the content validity of the COMM was acceptable.

The construct validity was determined by principal components factor analysis with Oblimin rotation. The result of the $\mathrm{KMO}$ measure was 0.68 and the approximate chi-square for Bartlett's test was 496451 ( $d f=136, p<0.001)$. Table 6 shows the factor loadings of all 17 items: they ranged from 0.41 (item 3) to 0.75 (item 12). Six principal components were extracted with eigenvalue of $4.04,2.02,1.69,1.22$, 1.19 and 1.08, respectively. Items $1,3,5,6,7,8,10,11$, 13 and 16 load on factor 1; Item 4, 9 and 14 load on factor 2; Item 17 load on factor 3; Item 15 load on factor 4; Item 12 load on factor 5 and finally item 2 load on factor 6 . The percent variances for the six factors were $23.8 \%, 11.9 \%$, $10.0 \%, 7.2 \%, 7.0 \%$ and $6.4 \%$, respectively.

\section{DISCUSSION}

Guidelines and a model of principles for good practice ${ }^{19}$ were followed culminating in the creation of a properly translated and culturally adapted version of COMM. Moreover, we also showed feasibility for the use of COMM in Portuguese chronic pain patients.

Self-report instruments may be one viable strategy for screening aberrant opioid-related behaviors. ${ }^{14}$ Until now, there were no Portuguese versions of these instruments; 
Table 3 - Average responses of Portuguese COMM translation $(n=98)$

1. Nos últimos 30 dias, com que frequência teve dificuldade em pensar com clareza ou teve problemas de memória?

1.84 ( \pm 1.47); [0 - 4]

2. Nos últimos 30 dias, com que frequência é que alguém reclamou que não está a completar tarefas necessárias? (por exemplo, fazer coisas que precisam de ser feitas, tais como ir às aulas, trabalho ou compromissos)

$0.77( \pm 1.17) ;[0-4]$

3. Nos últimos 30 dias, com que frequência teve de contactar com mais alguém, para além do seu médico que Ihe prescreve a medicação, para obter alívio suficiente da dor através de medicação? (por exemplo, outro médico, serviço de urgência, amigos, pessoas na rua)

4. Nos últimos 30 dias, com que frequência tomou os seus medicamentos de forma diferente à que Ihe foi prescrita pelo médico?

5. Nos últimos 30 dias, com que frequência pensou seriamente em magoar-se?

6. Nos últimos 30 dias, quanto do seu tempo foi gasto a pensar na medicação opióide (por exemplo, ter medicação suficiente, tomá-la, horários de toma)?

7. Nos últimos 30 dias, com que frequência teve discussões?

8. Nos últimos 30 dias, com que frequência teve problemas em controlar a sua raiva (por exemplo, fúria ao volante, gritar, etc.)?

9. Nos últimos 30 dias, com que frequência precisou de tomar medicação para a dor, pertencente a outra pessoa?

10. Nos últimos 30 dias, com que frequência esteve preocupado com o modo como está a controlar a sua medicação (por exemplo, sentimentos de angústia, ansiedade, medo e/ou raiva)?

11. Nos últimos 30 dias, com que frequência outras pessoas estiveram preocupadas com o modo como está a controlar a sua medicação?

12. Nos últimos 30 dias, com que frequência teve de fazer chamadas telefónicas de emergência ou aparecer na consulta sem marcação?

13. Nos últimos 30 dias, com que frequência ficou zangado com pessoas?

14. Nos últimos 30 dias, com que frequência teve que tomar mais medicamentos do que os prescritos?

15. Nos últimos 30 dias, com que frequência pediu emprestada a alguém medicação para a dor?

16. Nos últimos 30 dias, com que frequência usou a sua medicação da dor para sintomas diferentes de dor (por exemplo, para o ajudar a dormir, melhorar o humor ou aliviar o stress)?

$0.73( \pm 1.09) ;[0-4]$

0.88 ( \pm 1.29); [0 - 4]

0.61 ( \pm 1.10$) ;[0-4]$

1.05 ( \pm 1.33); [0 - 4]

0.95 ( \pm 1.27 ); [0 - 4]

0.98 ( \pm 1.22); [0 - 4]

0.02 ( \pm 0.20$) ;[0-4]$

1.17 ( \pm 1.40$) ;[0$ - 4]

1.15 ( \pm 1.43); [0 - 4]

0.70 ( \pm 1.19); [0 - 4]

1.09 ( \pm 1.19); [0 - 4]

0.78 ( \pm 1.15); [0 - 4]

0.01 ( \pm 0.10 ); [0 - 1]

0.65 ( \pm 1.17$) ;[0$ - 5]

17. Nos últimos 30 dias, com que frequência teve de ir ao Serviço de Urgência?

0.54 ( \pm 1.16); [0 - 4]

SD: standard deviation

Table 4 - Inter-item average correlation sorted by 17 questions of COMM

\begin{tabular}{|c|c|c|c|c|c|c|c|c|c|c|c|c|c|c|c|c|c|}
\hline Item & 1 & 2 & 3 & 4 & 5 & 6 & 7 & 8 & 9 & 10 & 11 & 12 & 13 & 14 & 15 & 16 & 17 \\
\hline 1 & 1.00 & & & & & & & & & & & & & & & & \\
\hline 2 & $0.27^{* *}$ & 1.00 & & & & & & & & & & & & & & & \\
\hline 3 & $0.19^{*}$ & 0.17 & 1.00 & & & & & & & & & & & & & & \\
\hline 4 & 0.08 & 0.08 & $0.26^{* *}$ & 1.00 & & & & & & & & & & & & & \\
\hline 5 & $0.25^{* *}$ & 0.07 & $0.35^{* *}$ & 0.13 & 1.00 & & & & & & & & & & & & \\
\hline 6 & $0.35^{* *}$ & 0.12 & $0.33^{* *}$ & 0.13 & $0.34^{* *}$ & 1.00 & & & & & & & & & & & \\
\hline 7 & $0.32^{* *}$ & $0.18^{*}$ & 0.11 & 0.16 & 0.15 & 0.31 & 1.00 & & & & & & & & & & \\
\hline 8 & $0.28^{* *}$ & $0.19^{*}$ & 0.15 & $0.24^{* *}$ & $0.34^{* *}$ & $0.25^{\star *}$ & 0.24 & 1.00 & & & & & & & & & \\
\hline 9 & -0.13 & -0.08 & 0.13 & 0.16 & -0.07 & -0.09 & -0.08 & -0.09 & 1.00 & & & & & & & & \\
\hline 10 & 0.29 ** & $0.18^{*}$ & $0.27^{* *}$ & $0.23^{*}$ & $0.21^{*}$ & $0.46^{* *}$ & 0.09 & 0.13 & -0.09 & 1.00 & & & & & & & \\
\hline 11 & $0.18^{*}$ & $0.21^{*}$ & $0.19^{*}$ & 0.29 ** & 0.08 & $0.34^{* *}$ & 0.05 & 0.11 & 0.13 & $0.75^{* *}$ & 1.00 & & & & & & \\
\hline 12 & -0.02 & 0.09 & 0.10 & 0.02 & $0.24^{* *}$ & 0.07 & -0.11 & 0.13 & 0.14 & 0.05 & 0.08 & 1.00 & & & & & \\
\hline 13 & $0.28^{* *}$ & 0.09 & 0.04 & $0.23^{*}$ & $0.44^{* *}$ & 0.15 & $0.37^{* *}$ & $0.51^{* *}$ & -0.11 & 0.09 & 0.09 & 0.11 & 1.00 & & & & \\
\hline 14 & 0.05 & 0.08 & $0.27^{* *}$ & $0.60^{* *}$ & 0.11 & 0.02 & -0.06 & $0.34^{* *}$ & $0.20^{*}$ & 0.08 & 0.15 & 0.10 & 0.11 & 1.00 & & & \\
\hline 15 & 0.15 & 0.08 & 0.08 & 0.07 & 0.16 & 0.10 & 0.11 & 0.04 & -0.01 & 0.03 & -0.09 & 0.10 & 0.10 & 0.08 & 1.00 & & \\
\hline 16 & 0.14 & -0.05 & $0.28^{* *}$ & $0.35^{* *}$ & $0.18^{*}$ & $0.29^{* *}$ & $0.21^{* *}$ & $0.31^{* *}$ & 0.15 & $0.45^{* *}$ & $0.38^{* *}$ & $0.17^{*}$ & 0.11 & $0.34^{* *}$ & 0.11 & 1.00 & \\
\hline 17 & 0.14 & 0.01 & 0.01 & 0.11 & 0.07 & -0.05 & -0.03 & 0.06 & $0.17^{*}$ & 0.02 & -0.10 & 0.05 & $0.28^{*}$ & $0.17^{*}$ & $0.21^{*}$ & 0.04 & 1.00 \\
\hline
\end{tabular}


therefore, the Portuguese version of COMM is the first instrument that will allow this screening in Portuguese chronic pain patients.

Item means in our questionnaire were similar to those presented in the original version ${ }^{17}$ with two notable excep-

Table 5 - Item-total correlation and Cronbach's alpha sorted by all 17 questions of COMM

\begin{tabular}{ccc}
\hline Question & $\begin{array}{c}\text { Corrected item-total } \\
\text { correlation }\end{array}$ & $\begin{array}{c}\text { Cronbach's Alpha } \\
\text { if item deleted }\end{array}$ \\
\hline 1 & 0.41 & 0.764 \\
2 & 0.24 & 0.776 \\
3 & 0.32 & 0.770 \\
4 & 0.44 & 0.761 \\
5 & 0.53 & 0.755 \\
6 & 0.54 & 0.751 \\
7 & 0.35 & 0.768 \\
8 & 0.51 & 0.755 \\
9 & $0.05^{\dagger}$ & 0.780 \\
10 & 0.56 & 0.749 \\
11 & 0.47 & 0.757 \\
12 & $0.08^{\dagger}$ & $0.788^{\S}$ \\
13 & 0.43 & 0.761 \\
14 & 0.30 & 0.772 \\
15 & $0.10^{\dagger}$ & 0.780 \\
16 & 0.53 & 0.754 \\
17 & $0.12^{\dagger}$ & $0.784 \S$ \\
\hline
\end{tabular}

II A global Cronbach's Alpha of 0.778 was found; $\uparrow$ : Item-total correlation less than 0.20 ; $\S:$ Cronbach's alpha increases if item deleted

Table 6 - Factors extracted, Eingeinvalues and variance explained by those factors

\begin{tabular}{|c|c|c|c|c|c|c|}
\hline Item & Factor 1 & Factor 2 & Factor 3 & Factor 4 & Factor 5 & Factor 6 \\
\hline 1 & 0.51 & -0.34 & -0.09 & 0.46 & 0.02 & 0.07 \\
\hline 3 & 0.41 & 0.24 & -0.17 & 0.11 & 0.36 & 0.17 \\
\hline 5 & 0.65 & -0.28 & 0.25 & -0.21 & 0.30 & -0.14 \\
\hline 6 & 0.68 & -0.23 & -0.24 & -0.03 & 0.06 & -0.14 \\
\hline 7 & 0.51 & -0.41 & 0.07 & -0.05 & -0.36 & 0.24 \\
\hline 8 & 0.63 & -0.22 & 0.30 & -0.23 & 0.11 & 0.29 \\
\hline 10 & 0.68 & 0.14 & -0.49 & 0.01 & -0.07 & -0.37 \\
\hline 11 & 0.59 & 0.32 & -0.52 & 0.02 & -0.09 & -0.18 \\
\hline 13 & 0.55 & -0.36 & 0.48 & -0.16 & -0.13 & 0.04 \\
\hline 16 & 0.65 & 0.27 & 0.09 & -0.23 & -0.22 & -0.28 \\
\hline 4 & 0.52 & 0.55 & 0.19 & -0.03 & -0.26 & 0.23 \\
\hline 9 & 0.01 & 0.57 & 0.18 & 0.08 & 0.11 & 0.03 \\
\hline 14 & 0.35 & 0.69 & 0.26 & 0.01 & 0.00 & 0.34 \\
\hline 17 & 0.15 & 0.12 & 0.51 & 0.51 & -0.13 & -0.28 \\
\hline 15 & 0.11 & -0.14 & 0.39 & 0.60 & 0.05 & -0.29 \\
\hline 12 & 0.11 & 0.12 & 0.25 & -0.18 & 0.75 & -0.23 \\
\hline 2 & 0.31 & -0.17 & -0.38 & 0.38 & 0.29 & 0.49 \\
\hline Eigenvalue & 4.04 & 2.02 & 1.69 & 1.22 & 1.19 & 1.08 \\
\hline $\begin{array}{l}\text { Total variance explained by each factor } \\
\text { (accumulated) }\end{array}$ & $23.8 \%$ & $\begin{array}{c}11.9 \% \\
(35.7 \%)\end{array}$ & $\begin{array}{c}10.0 \% \\
(45.7 \%)\end{array}$ & $\begin{array}{c}7.2 \% \\
(52.9 \%)\end{array}$ & $\begin{array}{c}7.0 \% \\
(59.9 \%)\end{array}$ & $\begin{array}{c}6.4 \% \\
(66.3 \%)\end{array}$ \\
\hline
\end{tabular}

tions. Questions number 9 and 15 had very low average scores: 0.02 and 0.01 respectively, while in the original the average was 0.14 to both questions. These questions allude to the concept of taking/borrowing medication from someone else. In a recent systematic review, which comprised 19 studies from nine countries (eight conducted in the United States, four in Australia, two in New Zealand, and one each in Canada, Nigeria, Malaysia, Qatar, and Ireland), the prevalence estimates for borrowing someone's prescription medication varied between $5 \%$ to $51.9 \%{ }^{30}$ There are no estimates regarding this concept in Portugal and this should be addressed in future studies. Differences in cultures, health care systems, economics, education, and medication use behaviors could explain differences among countries. Misuse can take many shapes and be characterized by a whole range of behaviors. Once the concepts of taking/borrowing medication try to measure one dimension of misuse, one can postulate that, if it exists, the act of borrow and take medication belonging from someone does not appear to be frequent or relevant in our setting. However, concealment of information due to fear of reprisals cannot be ruled out.

Regarding internal consistency, a global Cronbach's alpha of 0.778 was found, denoting good internal consistency. This value is in accordance with those obtained in previous translations and with the original COMM article of Butler et al. ${ }^{17}$

Item-total correlation showed that item 9, 12, 15 and 17 don't correlate well with the total of the scale. Cronbach's alpha if item deleted suggested that removing questions number 12 and 17 from the questionnaire could lead to a 
higher internal consistency. Questions number 12 and 17 try to capture the dimension of 'appointment patterns'. ${ }^{17}$ Their deletion could make the questionnaire more reliable in the Portuguese setting, suggesting that these items contribute in a lesser extent to internal consistency of the questionnaire. However, other criteria such as relevance of the item need to be taken in account in the decision of its removal. Moreover, the elimination of these questions would result in loss of two factors and this content would not be compensated by any other factor.

Additionally, inter-item average correlation showed weak or negative item correlations for some of the questions. This suggests that COMM is not a unidimensional measurement which is in agreement with the different dimensions explored in the original questionnaire (signs and symptoms of drug misuse; emotional problems/psychiatric issues; appointment patterns; evidence of lying and drug use; medication misuse e noncompliance). ${ }^{17}$

Concerning test-retest reliability, one-month test-retest was excellent (ICC $=0.90$, with a $95 \%$ confidence interval ranging between 0.76 and 0.96 ). Our value was in line with previous translations and was even higher than the one found by Butler et al. ${ }^{17,18}$

Towards validity, the CVI was excellent, showing that all seventeen items evaluate the same construct as an overall instrument. In the original COMM, the 17 items were allocated to five clusters/dimensions: Signs and symptoms of drug misuse, Emotional problems/psychiatric issues, Appointment patterns, Evidence of lying and drug use and Medication misuse and noncompliance. ${ }^{17}$ According to the results of factor analysis, all the 17 items of the COMM were grouped into six factors, with factor loadings reaching the criteria of 0.40 . This shows that the construct of the Portuguese version did not keep in accordance with what was originally intended. ${ }^{17}$ In fact, the first factor was labeled "Negative feelings or actions" (item 1, 3, 5, 6, 7, 8, 10, 11, 13 and 16), the second "Medication misuse" (item 4, 9 and 14 ), the third "Need to have access to the ER" (item 17), the fourth "Aberrant relation with others" (item 15), the fifth "Need to have access to health care" (item 12) and sixth "Protest to patient" (item 2). These six possible underlying dimensions of the COMM explained $66.3 \%$ of the variance.

Our study has several strengths. To our knowledge, it was the first successful attempt to translate, culturally adapt and validate an instrument to assess aberrant opioidrelated behaviors in Portugal. Therefore, the Portuguese version of COMM is a unique instrument that will aid and promote the screening of aberrant opioid-related behaviors in Portuguese chronic pain patients. This will allow the development of treatment strategies designed to minimize continued misuse, which will reduce morbidity and mortality related with aberrant opioid-related behaviors. Additionally, it may serve as a useful tool for those providers who need to document their patient's compliance and appropriate use of opioids in Portuguese chronic pain patients. The results of this measure may have the added benefit of reducing physician's concerns related to opioid prescribing, and may keep patients more aware of their need to be responsible with these medications. ${ }^{31}$ Secondly, guidelines and a model of principles for good practice in the translation, cultural adaptation and validation of questionnaires were strictly followed which reinforces its validity and quality. Third, as shown in our patient characteristics, it is likely that our sample was representative, favoring external validity.

There are also some limitations in this study. Firstly, our sample comes from a single hospital, which could result in some bias regarding demographic differences and selection of opioids in chronic pain treatment that might be a threat to generalizability. However, is important to emphasize that our hospital, as a tertiary centre, receives a wide variety of chronic pain patients with different pain classifications and prescribes several regimens of opioid treatment, which is reflected in this sample. Theoretically, patients prescribed with strong opioids are those who are at higher risk of aberrant opioid-related behaviors, and most of the patients from our sample were prescribed with strong opioids. Secondly, although the sample size respected the established guidelines, ${ }^{32}$ a higher number could have allowed additional conclusions. Finally, criterion validity of COMM was not analyzed with other tools because there are no Portuguese version tools to assess it. In order to obviate that, a panel of experts in chronic pain was recruited which allowed the estimation of content validity, which was acceptable.

\section{CONCLUSION}

The Portuguese version of COMM was successfully translated and adapted to the Portuguese setting. It presented good internal consistency, validity and test-retest reliability.

This questionnaire is expected to offer clinicians a tool to aid and promote the screening of aberrant opioid-related behaviors, in Portuguese chronic pain patients currently on opioid therapy, apart from assessing their treatment compliance.

Consequently, the implementation of this questionnaire may reduce the incidence and morbimortality related with opioid misuse; and should improve chronic pain treatment in Portugal, namely by reducing the concerns of physicians regarding opioid prescribing and by increasing patient awareness of the responsibility of being on opioid therapy.

\section{ACKNOWLEDGEMENTS}

The authors would like to thank all nurses and doctors of chronic pain unit of CHUSJ for the provision of facilities and for the support provided.

\section{PROTECTION OF HUMANS AND ANIMALS}

The authors declare that the procedures were followed according to the regulations established by the Clinical Research and Ethics Committee and to the Helsinki Declaration of the World Medical Association.

\section{DATA CONFIDENTIALITY}

The authors declare having followed the protocols in 
use at their working center regarding patients' data publication.

\section{CONFLICTS OF INTEREST}

All authors report no conflict of interest.

\section{REFERENCES}

1. Dysvik E, Lindstrom T, Eikeland O, Natvig G. Health-related quality of life and pain beliefs among people suffering from chronic pain. Pain Manag Nurs. 2004;5:66-74

2. Fernandez-de-las-Penas $\mathrm{C}$, Hernandez-Barrera $\mathrm{V}$, Alonso-Blanco C, Palacios-Ceña D, Carrasco-Garrido P, Jiménez-Sánchez $S$, et al. Prevalence of neck and low back pain in community-dwelling adults in Spain: a population-based national study. Spine. 2011;36:E213-9.

3. Raftery M, Sarma K, Murphy A, De la Harpe D, Normand C, McGuire B. Chronic pain in the Republic of Ireland-community prevalence, psychosocial profile and predictors of pain-related disability: results from the Prevalence, Impact and Cost of Chronic Pain (PRIME) study, part 1. Pain. 2011;152:1096-103

4. Kurita G, Sjogren P, Juel K, Hojsted J, Ekholm O. The burden of chronic pain: a cross-sectional survey focussing on diseases, immigration, and opioid use. Pain. 2012;153:2332-8.

5. Landmark T, Romundstad P, Dale O, Borchgrevink PC, Vatten L, Kaasa S. Chronic pain: one year prevalence and associated characteristics (the HUNT pain study). Scand J Pain. 2013;4:182-7.

6. Gunnarsdottir S, Ward S, Serlin R. A population based study of the prevalence of pain in Iceland. Scand J Pain. 2010;1:151-7.

7. Azevedo L, Costa-Pereira A, Mendonca L, Dias C, Castro-Lopes J. Epidemiology of chronic pain: a population-based nationwide study on its prevalence, characteristics and associated disability in Portugal. J Pain. 2012;13:773-83.

8. O'Brien T, Christrup L, Drewes A, Fallon M, Kress H, McQuay H, et al. European Pain Federation position paper on appropriate opioid use in chronic pain management. Eur J Pain. 2017;21:3-19.

9. Manchikanti L, Singh A. Therapeutic opioids: a ten-year perspective on the complexities and complications of the escalating use, abuse, and nonmedical use of opioids. Pain Physician. 2008;11:S63-88.

10. Azevedo L, Costa-Pereira A, Mendonca L, Dias C, Castro-Lopes J. A population-based study on chronic pain and the use of opioids in Portugal. Pain. 2013;154:2844-52.

11. Benyamin R, Trescot AM, Datta S, Buenaventura R, Adlaka R, Sehgal $\mathrm{N}$, et al. Opioid complications and side effects. Pain Physician. 2008;11:S105-20

12. Vowles K, McEntee M, Julnes P, Frohe T, Ney J, van der Goes D. Rates of opioid misuse, abuse, and addiction in chronic pain: a systematic review and data synthesis. Pain. 2015;156:569-76.

13. Chou R, Fanciullo G, Fine P, Adler J, Ballantyne J, Davies P, et al. Clinical guidelines for the use of chronic opioid therapy in chronic noncancer pain. J Pain. 2009;10:113-30.

14. McCaffrey S, Black R, Villapiano A, Jamison R, Butler S. Development of a brief version of the Current Opioid Misuse Measure (COMM): the COMM-9. Pain Med. 2019;20:113-8.

15. Larance B, Degenhardt L, Lintzeris N, Winstock A, Mattick R. Definitions related to the use of pharmaceutical opioids: extramedical use, diversion, non-adherence and aberrant medication-related behaviours. Drug Alcohol Rev. 2011;30:236-45.

16. Merlin J, Turan J, Herbey I, Westfall A, Starrels J, Kertesz S, et al.

\section{FUNDING SOURCES}

This research received no specific grant from any funding agency in the public, commercial, or not-for-profit sectors.

Aberrant drug-related behaviors: a qualitative analysis of medical record documentation in patients referred to an HIV/Chronic pain clinic. Pain Med. 2014;15:1724-33.

17. Butler S, Budman S, Fernandez K, Houle B, Benoit C, Katz N, et al. Development and validation of the Current Opioid Misuse Measure. Pain. 2007;130:144-56.

18. Zhao Y, Li Y, Zhang X, Lou F. Translation and validation of the Chinese version of the Current Opioid Misuse Measure (COMM) for patients with chronic pain in Mainland China. Health Qual Life Outcomes. 2015;13:147.

19. Wild D, Grove A, Martin M, Eremenco S, McElroy S, Verjee-Lorenz A, et al. Principles of good practice for the translation and cultural adaptation process for Patient-Reported Outcomes (PRO) measures: report of the ISPOR Task Force for Translation and Cultural Adaptation. Value Health. 2005;8:94-104.

20. Tsang S, Royse C, Terkawi A. Guidelines for developing, translating, and validating a questionnaire in perioperative and pain medicine. Saudi $J$ Anaesth. 2017;11:S80-9.

21. Santos J, Brito J, de Andrade D, Kaziyama V, Ferreira K, Souza I, et al. Translation to Portuguese and validation of the Douleur Neuropathique 4 questionnaire. J Pain. 2010;11:484-90.

22. Sa A, Sousa G, Santos A, Santos C, Abelha F. Quality of recovery after anesthesia: validation of the Portuguese version of the 'Quality of Recovery 15' questionnaire. Acta Med Port. 2015;28:567-74.

23. Polit $D$, Beck $C$. The content validity index: are you sure you know what's being reported? Critique and recommendations. Res Nurs Health. 2006;29:489-97.

24. Costa-Santos C, Antunes L, Souto A, Bernardes J. Assessment of disagreement: a new information-based approach. Ann Epidemiol. 2010;20:555-61.

25. Peterson R. A meta-analysis of Cronbach's coefficient alpha. J Consum Res. 1994;21:381-91.

26. DeVellis R. Scale development: theory and applications. Thousand Oaks: SAGE; 2012.

27. Bartko J. The intraclass correlation coefficient as a measure of reliability Psychol Rep. 1966;19:3-11.

28. Bartlett M. Tests of significance in factor analysis. $\mathrm{Br} \mathrm{J}$ Math Stat Psychol. 1950;3:77-85.

29. Wakefield D, Wakefield B, Uden-Holman T, Borders T, Blegen M, Vaughn $\mathrm{T}$. Understanding why medication administration errors may not be reported. Am J Med Qual. 1999;14:81-8.

30. Beyene K, Sheridan J, Aspden T. Prescription medication sharing: a systematic review of the literature. Am J Public Health. 2014;104:e1526.

31. Butler S, Budman S, Fanciullo G, Jamison R. Cross validation of the current opioid misuse measure to monitor chronic pain patients on opioid therapy. Clin J Pain. 2010;26:770-6.

32. Gorsuch R. Factor analysis. $2^{\text {nd }}$ ed. Hillsdale: Lawrence Erlbaum Associates; 1983 